\title{
Phytoestrogen Enriched Tofu from Soybean Meal
}

\author{
Su Hyeon Hwang ${ }^{1,2}$, Pushparajah Thavarajah ${ }^{1 *}$, Dilrukshi Thavarajah ${ }^{1}$ \\ ${ }^{1}$ School of Food Systems, North Dakota State University (NDSU), Fargo, USA; ${ }^{2}$ Department of Food Science and Technology, \\ Seoul Women's University, Seoul, Republic of Korea. \\ Email: *pushparajah.thavaraj@ndsu.edu
}

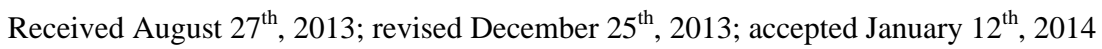

Copyright (C) 2014 Su Hyeon Hwang et al. This is an open access article distributed under the Creative Commons Attribution License, which permits unrestricted use, distribution, and reproduction in any medium, provided the original work is properly cited. In accordance of the Creative Commons Attribution License all Copyrights (C) 2014 are reserved for SCIRP and the owner of the intellectual property Su Hyeon Hwang et al. All Copyright (C) 2014 are guarded by law and by SCIRP as a guardian.

\begin{abstract}
Isoflavone, a group of phytoestrogen, reduces postmenopausal symptoms and the risk of osteoporosis of women. Glycosidic forms of isoflavones are presented in non-fermented soyfoods such as tofu and they are less bioavailable than the aglycone isoflavones. Aglycone forms of isoflavones or more bioavailable forms can be increased by acid hydrolysis during tofu processing. The present study investigated the possibility of increasing the aglycone forms of isoflavones by acid hydrolysis. We used five types of tofu in this study: soybean tofu with hydrolysis, soybean meal tofu with hydrolysis, soybean tofu in general process, soybean meal tofu in general process, and commercial tofu. Defatted soybean meal was used as the major ingredient in the tofu which was made by using the new method-acid hydrolysis. To identify the isoflavone quantities in all five types of tofu, high performance liquid chromatography with diode array detection (HPLC-DAD) analysis was employed. The genistein ratio between hydrolyzed tofu and standard tofu was $1: 1-8$, and the daidzein ratio between hydrolyzed tofu and standard tofu was 1:6-12. The five types of tofu were analyzed for the crude protein and micronutrients such as calcium (Ca), magnesium (Mg), potassium (K), iron (Fe), zinc (Zn), and selenium (Se) by the modified Kjeldahl method and inductively coupled plasma emission spectroscopy (ICP-ES), respectively. The mean crude protein concentration of hydrolyzed tofu from soybean meal was $\mathbf{4 0 . 8 \%}$. In addition, especially the hydrolyzed soybean meal tofu showed the higher concentration of Ca (27,307 mg/kg) and K (25,553 mg/kg). By and large, soybean meal tofu with acid hydrolysis is a rich source of isoflavone aglycone compared with other types of tofu.
\end{abstract}

\section{KEYWORDS}

Tofu; Soybean Meal; Isoflavone; Aglycone; Daidzein; Genistein

\section{Introduction}

Soybean products are the source of phytochemicals with the range of nutritional benefits. Among many soybean products, tofu is the most popular soy food product in Korea, Japan, and China. According to US soyfood directory, raw regular tofu contains $84.6 \%$ water, $1.9 \%$ carbohydrates, $8.1 \%$ protein, $4.8 \%$ fat, and a range of micronutrients, and phytoestrogen, especially isoflavone. Tofu is, not only rich in proteins and unsaturated fatty acids, but also, it is rich in range of isoflavones. Isoflavone, a class of plant-derived phytoestrogen, compounds with estrogenic activity. These phytoestrongens have si-

"Corresponding author. milar molecular structures as of human, animal, or synthetic estrogens. Thus, it can easily bind to an estrogen receptor. Isoflavones show beneficial pharmacological and physiological effects on human health [1]. It has been hypothesized that isoflavones may lower the risk of cancers in breast, prostate, urinary tract, and colon. Moreover, increased isoflavone consumption reduced coronary heart disease and osteoporosis [2].

Isoflavone is defined as a class of isoflavonoids that characteristically has apolyphenolic structure [3]. They are found in legumes, and grains such as wheat, corn, and oats. Among these crops, soybean has the highest isoflavone concentration. According to USDA, the total isoflavone (genistein, daidzein, and glycitein) concentration 
of raw soybean mature seeds is $155 \mathrm{mg} / 100 \mathrm{~g}$. To date, 19 soybean isoflavones have been reported, and 12 types of isoflavones are regarded as the major isoflavones. It can be classified into four types depending on the chemical structure. Each type has three compounds [i.e., malonyl glycoside (malonyl genetin, malonyl daidzin, malonyl glycitin) and acetyl-beta glycosides, beta glycosides, and aglycones (genestein, daidzein, glycitein)] [4].

Although all isoflavones are efficiently absorbed from the intestinal tract, there are differences in the fate of aglycones and beta-glycosides in terms of absorption [5]. Aglycones of isoflavones have higher bioavailability than corresponding glycoside forms, as glycosidicisoflavones are not directly transported across the gastro intestinal tract [5]. Most soyfood products have a complex mixture of glycoside conjugates (genistin, daidzin, and glicytin). These isoflavone glycosides are hydrolyzed by intestinal, mucosal, and bacterial beta glucosidase. Probiotics such as Latobacillus and Bifidobacterium have been known to possess endogenous beta glucosidase. Thus, depending on the hydrolysis, the profile of isoflavone can be changed. This hydrolytic action leads to increase of bioactive isoflavone aglycones, which are then either absorbed directly or further metabolized by intestinal microflora in the large intestine into other metabolites [6].

In the 1960s, Japan started using defatted soybean meal in tofu preparation [7]. However, today, instead of soybean meal, whole soybeans are widely used in tofu preparation to obtain richer tofu flavor and nutritional value. The mealy texture deprives tofu of some of its cohesiveness, making it more breakable [7]. So far, there are no data available on the soybean meal tofu nutritional profiles. The evaluation of soybean meal tofu nutritional profiles is still important, especially, for developing countries as soybean meal based tofu might have potential to provide more nutritious, high protein based food source with less cost.

In comparison with the whole soybean, the soybean meal has higher composition of protein and amino acids, and lower fat concentration. For example, soybeans contain approximately $37 \%$ crude protein and $18 \%$ crude fat, and soybean meal contains $44 \%$ of crude protein and $3 \%$ of crude fat [8]. Therefore, soybean meal could be a good source for tofu preparation due to high isoflavone concentrations and low fat contents. This study was carried out to 1 ) determine the feasibility of tofu preparation using soybean meal from North Dakota, USA; 2) assess nutrient profiles and isoflavone concentrations in both soybean meal and soybean meal tofu prepared from the newest hydrolyzed method. As isoflavone bioavailability is critical for better human nutrition, in our study, we suggest a new tofu preparation procedure for improved isoflavone bioavailability.

\section{Materials and Methods}

\subsection{Materials}

Defatted soybean meal samples were collected from Northern Crops Institute, North Dakota State University, Fargo, ND and Hubbard Feeds Inc., Moorhead, MN, USA. Three types of commercially grown soybean (Glycine max L.) samples were obtained from the Department of Plant Sciences, North Dakota State University, Fargo, ND, USA. Seven commercially sold pre-packed tofu samples products were purchased from four local supermarkets in Fargo, ND, USA. All study samples were stored in a $4^{\circ} \mathrm{C}$ refrigerator until further processing and sample analysis. All samples were analyzed in triplicates.

\subsection{Preparation Soybean Meal and Soybean Tofu with Acid Hydrolysis}

Tofu was made on a laboratory scale. Before tofu preparation, approximately $200 \mathrm{~g}$ of the two types of defatted soybean meals were soaked in $1600 \mathrm{~mL}$ of water at room temperature $\left(25^{\circ} \mathrm{C}\right)$ for 3 hours, and the three types of whole soybeans were soaked for 12 hours in the same conditions. Then both the soybean meals and whole soybeans were ground in a household coffee grinder (Hamilton Beach Inc., NC, USA) to make a slurry. This resultant slurry was cooked to $100^{\circ} \mathrm{C}$ for 10 minutes. After cooking, the insoluble soy residue was filtered using a cloth. Approximately, $200 \mathrm{~mL}$ of the filtrate, (i.e., soy milk) was collected. For making general tofu, $20 \mathrm{~mL}$ of $10 \%$ calcium sulfate $\left(\mathrm{CaSO}_{4}\right)$ was added as a coagulant to the soymilk. On the other hand, for making hydrolyzed tofu, $200 \mathrm{~mL}$ of soymilk from soy bean and soybean milk were boiled with $20 \mathrm{~mL}$ of $4 \mathrm{M}$ hydrochloric acid $(\mathrm{HCl})$ to $100^{\circ} \mathrm{C}$ for 5 minutes. Then $20 \mathrm{~mL}$ of $10 \% \mathrm{CaSO}_{4}$ was added to coagulate, and $20 \mathrm{~mL}$ of $4 \mathrm{M}$ potassium hydroxide $(\mathrm{KOH})$ was added to neutralize. The precipitate was filtrated using acloth, and the supernatant was discarded.

\subsection{Isoflavone Extraction and HPLC Analysis}

All samples (two types of soybean meal tofu, three types of soybean tofu, and seven types of processed tofu) were dried in a vacuum oven (10 mmHg) (Napco Inc., VA, USA) at $60^{\circ} \mathrm{C}$ for 48 hours. Dried samples were ground using a household coffee blender (Hamilton Beach Inc., NC, USA). Two grams of dried, finely ground samples were placed in a $50 \mathrm{~mL}$ conical plastic tube to which 10 $\mathrm{mL}$ of acetonitrile, $2 \mathrm{~mL}$ of $0.1 \mathrm{M} \mathrm{HCl}$, and $5 \mathrm{~mL}$ of distilled water were added. The mixture was shaken for 2 hours using a mini incubating shaker (VWR International, IL, USA) for the complete isoflavone extraction. Extracted sample was filtered (No. 41 filter paper, What man, Hillsboro, OR, USA), and again through a $0.45 \mu \mathrm{m}$ 
membrane (VWR International, IL, USA).

Isoflavone profiles of dry ground tofu were performed on an Agilent 1200 series separation module attached to a Agilent 1200 series photodiode array detector (PDA) (Agilent Technologies Inc., Torrance, CA, USA) and a C18 column $(250 \times 4.60 \mathrm{~mm})$ (Prodigy 5u Phenomnex Inc, CA, USA). The photo diode array detector monitored absorbance from $200 \mathrm{~nm}$ to $350 \mathrm{~nm}$. The following standards were used for quantification purposes: daidzin, genistin, daidzein, and genistein (Sigma-Aldrich, St. Louis, USA). The mobile phase consisted of glacial acetic acid $(0.1 \% \mathrm{v} / \mathrm{v}$; eluent $\mathrm{A})$ and acetonitrile/glacial acetic acid (99.9:0.1, v/v; eluent B). All elutions were carried out at a flow rate of $1.0 \mathrm{~mL} / \mathrm{min}$ at $23^{\circ} \mathrm{C}$. The solvent gradient was as follows: After the injection of 20 $\mu \mathrm{L}$ of sample, solvent B was increased from $15 \%$ to $29 \%$ over $36 \mathrm{~min}$, then increased to $35 \%$ within the next $8 \mathrm{~min}$. From 44 min to $45 \mathrm{~min}$, solvent B was increased to $40 \%$, and finally to $45 \%$ within the following $5 \mathrm{~min}$. After that, solvent B was re-equilibrated back to $15 \%$. Solvent A was manipulated depending on solvent $\mathrm{B}$ gradient. The total run time was 55 minutes.

\subsection{Protein Analysis}

To calculate crude protein concentrations of tofu, modified AOAC official method (988.05) was used. Approximately, $0.2 \mathrm{~g}$ of dry ground tofu samples was transferred into the digestion tube in duplicates. Two catalyst tablets composed of $3.5 \mathrm{~g}$ of potassium sulfate $\left(\mathrm{K}_{2} \mathrm{SO}_{4}\right)$ and $0.4 \mathrm{~g}$ of copper (II) sulfate $\left(\mathrm{CuSO}_{4}\right)$ and $15 \mathrm{~mL}$ of $98 \%$ concentrated sulfuric acid $\left(\mathrm{H}_{2} \mathrm{SO}_{4}\right)$ were added into the tube. Tubes were placed in a preheated digestion block with heat shields at $420^{\circ} \mathrm{C}$, and then the exhaust manifold was covered. Water vacuum was run at high flow for 5 minutes, and the flow was reduced gradually with the closed fume hood. The samples were digested for 1 hour until the samples became a clear green color. After digestion, the samples were removed from the digestion block and the heat shields, and then cooled for 5 minutes with the exhaust system running. The exhaust manifold was removed and the samples were cooled for additional 5 minutes. To prevent solidification of samples, $10 \mathrm{~mL}$ distilled deionized water was added to each tube. Each sample was diluted with $90 \mathrm{~mL}$ distilled deionized water. The digestion tube filled with one third of water was seton the Kjeltec 1030 autoanalyzer (Tecator, Höganäs, Sweden), and the distillation was begun. To reduce the error, chemical blanks were run first. These served as the correction factor for calculations. After finishing the distillation cycle completely, the recorded values indicated the milliliters of $1 \mathrm{M} \mathrm{H}_{2} \mathrm{SO}_{4}$ which were titrated for each sample.

\subsection{Micronutrient Analysis}

Micronutrients, calcium (Ca), magnesium (Mg), potas- sium (K), iron (Fe), zinc ( $\mathrm{Zn})$, and selenium (Se), concentrations were determined using the modified $\mathrm{HNO}_{3}$ $\mathrm{H}_{2} \mathrm{O}_{2}$ digestion method [9]. Approximately, $0.5 \mathrm{~g}$ of ground tofu samples was digested with $6 \mathrm{~mL}$ of concentrated $70 \%$ nitric acid $\left(\mathrm{HNO}_{3}\right)$ for 1 hour at $90^{\circ} \mathrm{C}$. After hand shaking the digestion tubes, $3 \mathrm{~mL}$ of $30 \%$ hydrogen peroxide $\left(\mathrm{H}_{2} \mathrm{O}_{2}\right)$ were added to the samples and kept for $15 \mathrm{~min}$ at $90^{\circ} \mathrm{C}$. Afterwards, $3 \mathrm{~mL}$ of $6 \mathrm{M} \mathrm{HCl}$ were added and kept for $5 \mathrm{~min}$ at $90^{\circ} \mathrm{C}$, and then cooled to room temperature. Completely digested samples were diluted with millipore water until the final volume became $10 \mathrm{~mL}$. Mineral concentrations were determined by inductively couple plasma-emission spectrometry (ICPES; ICP-6500 Duo, Thermo Fisher Scientific, Pittsburg, PA, USA). Measurements of total potassium (K), magnesium (Mg), iron (Fe), zinc ( $\mathrm{Zn})$ and selenium (Se) using this modified method were validated using National Institute of Standards and Technology (NIST) standard reference material 1515a (apple leaves) and inter-laboratory standards.

\section{Results and Discussion}

In this study, to make nutritional tofu with increased concentrations of bioavailable aglycone, a modified standard tofu making processing was used. Therefore, the effect of applying acid hydrolysis to the standard tofu procedure was determined. By using the HPLC-DAD analysis, four isoflavones in tofu were quantified including aglycones (daidzein, genestein) and $\beta$-glycosides (daidzin, genistin). In our preliminary experiment, the isoflavone profile of defatted soybean meal was confirmed to have a higher content of isoflavone $\beta$-glycosides than general soybeans. We observed that the concentrations of genistin and daidzin in soybean meal were 17 and 9 times higher than in whole soybean. In addition, the ratio of isoflavone glycoside to aglycone is much higher in soybean meal than in whole soybean. In other words, as an ingredient source soybean meal was the optimal raw material for acid-hydrolyzed tofu. As a result, the concentration of isoflavone aglycones had a significant increase in the modified tofu made with the acid-hydrolysis than tofu made with the standard procedure. Hydrolyzed tofu and standard tofu were made by two ingredients: soybean and defatted soybean meal. As shown in Table 1, in the hydrolyzed soybean tofu and defatted soybean meal tofu, the mean total isoflavone aglycone concentrations were found to be $203 \mu \mathrm{g} / \mathrm{mg}$ and $556 \mu \mathrm{g} / \mathrm{mg}$, respectively. Without hydrolysis, in the normal soybean tofu and defatted soybean meal tofu, the mean total isoflavone aglycone concentrations were 140 $\mu \mathrm{g} / \mathrm{mg}$ and $138 \mu \mathrm{g} / \mathrm{mg}$, respectively, and the average total aglycone concentration in commercial tofu was $253 \mu \mathrm{g} /$ mg. On average, the aglycone concentration of tofu made by soybean meal was increased 4 fold during acid 
Table 1. Isoflavone concentrations in different types of Tofu.

\begin{tabular}{|c|c|c|c|c|c|}
\hline & \multirow{2}{*}{ Tofu sample type } & \multicolumn{2}{|c|}{ ß-Glucoside } & \multicolumn{2}{|c|}{ Aglycone } \\
\hline & & Daidzin $(\mu \mathrm{g} / \mathrm{mg})$ & Genestin $(\mu \mathrm{g} / \mathrm{mg})$ & Daidzein $(\mu \mathrm{g} / \mathrm{mg})$ & Genestein $(\mu \mathrm{g} / \mathrm{mg})$ \\
\hline \multirow{4}{*}{$\begin{array}{l}\text { Soybean Tofu } \\
\text { with Hydrolysis }\end{array}$} & Prosoy & 627.34 & ND & 609.74 & ND \\
\hline & ND $1005 T$ & 332.21 & ND & ND & ND \\
\hline & P.91M10 & ND & ND & ND & ND \\
\hline & Mean \pm SD & $319.85 \pm 256.26$ & - & $203.25 \pm 287.44$ & - \\
\hline \multirow{3}{*}{$\begin{array}{l}\text { Soybean Meal } \\
\text { Tofu with } \\
\text { Hydrolysis }\end{array}$} & Northern Crops Institute & 671.58 & 402.75 & 324.79 & 382.19 \\
\hline & Hubbard Feeds Inc. & 1923.97 & 794.56 & 183.79 & 221.10 \\
\hline & Mean \pm SD & $1297.77 \pm 626.20$ & $598.65 \pm 195.91$ & $254.29 \pm 70.50$ & $301.64 \pm 80.55$ \\
\hline \multirow{4}{*}{$\begin{array}{l}\text { Soybean Tofu in } \\
\text { General Process }\end{array}$} & Prosoy & 1200.74 & 770.93 & 53.59 & 75.18 \\
\hline & ND $1005 \mathrm{~T}$ & 873.49 & 566.46 & 27.78 & 50.84 \\
\hline & P.91M10 & 1086.72 & 531.04 & 87.65 & 125.54 \\
\hline & Mean \pm SD & $1053.65 \pm 135.63$ & $622.81 \pm 105.73$ & $56.34 \pm 24.52$ & $83.85 \pm 31.10$ \\
\hline \multirow{3}{*}{$\begin{array}{c}\text { Soybean Meal } \\
\text { Tofu in General } \\
\text { Process }\end{array}$} & Northern Crops Institute & 1173.55 & 869.80 & 27.48 & 45.03 \\
\hline & Hubbard Feeds Inc. & 975.07 & 1021.03 & 0.00 & 202.84 \\
\hline & Mean \pm SD & $1074.31 \pm 99.24$ & $945.41 \pm 75.61$ & $13.74 \pm 13.74$ & $123.94 \pm 78.90$ \\
\hline \multirow{8}{*}{ Commercial Tofu } & Azumaya firm tofu & 341.03 & 788.35 & 64.98 & 154.73 \\
\hline & Nasoya extra firm tofu & 475.42 & 740.34 & 94.45 & 198.48 \\
\hline & Pulmuone soft tofu & 556.38 & 621.45 & 96.71 & 135.90 \\
\hline & Melissa’s extra firm tofu & 1032.63 & 593.24 & 55.58 & 91.91 \\
\hline & Wildwood firm sprou tofu & 974.83 & 540.19 & 55.44 & 90.56 \\
\hline & Mori-nu silken extra firm tofu & 288.17 & 457.15 & 212.85 & 369.98 \\
\hline & House feeds premium extra firm tofu & 806.69 & 595.70 & 63.00 & 89.93 \\
\hline & Mean \pm SD & $639.31 \pm 278.08$ & $619.49 \pm 104.90$ & $91.86 \pm 51.92$ & $161.64 \pm 92.99$ \\
\hline
\end{tabular}

SD = Standard deviation, ND = Not detected.

hydrolysis, and the defatted soybean meal provided by Northern Crops Institute contained the highest value of aglycone (707 $\mu \mathrm{g} / \mathrm{mg})$. In detail, in the hydrolyzed soybean meal tofu, isoflavone aglycone concentrations of genistein increased 1- to 8-fold, and daidzein, 6- to 12 -fold in all the samples. Although the total aglycone concentrations ranged widely, according to the report of tofu-type soy varieties, ratios of genistein to daidzein were stable around 1.4 [10]. However, in the hydrolyzed soybean tofu, only sample prosoy had $610 \mu \mathrm{g} / \mathrm{mg}$ of daidzein, and none of the isoflavone aglycones were detected in other types of soybean such as ND1005T and P.91M10. This may occur, because the tofu may get overboiled, and the over-boiling may cause severe acid hydrolysis leading aglycone to be changed into a different form.

The crude protein concentrations of all types of tofu are presented in Table 2. Notably, acid hydrolysis had a significant effect on crude protein concentration. The raw ingredient-soybean meal from Hubbard Feeds Inc.had $46 \%$ of crude protein; however, during standard tofu making $13.6 \%$ protein was lost, and when acid hydroly- sis occurred $16 \%$ of crude protein was lost. The mean crude protein concentration of commercial tofu was recorded at $56 \%$ by the modified Kjeldahl method. The protein concentration in commercial tofu was superior than lab-scale tofu. One reason for this can be the external protein sources added during commercial tofu preparation.

During tofu preparation in the laboratory, $\mathrm{CaSO}_{4}$ was used as a coagulant. This is because, $\mathrm{CaSO}_{4}$ was found to be the most suitable coagulant for tofu making in terms of its high yield, retention of maximum amount of isoflavones, and in obtaining a firm, but not as hard as the texture of tofu [11]. Table 3 shows the concentrations of $\mathrm{Ca}, \mathrm{K}, \mathrm{Mg}, \mathrm{Zn}, \mathrm{Fe}$, and $\mathrm{P}$ for all tofu samples. In the soybean meal tofu with hydrolysis, the mean total Ca concentration was $27,306 \mathrm{mg} / \mathrm{kg}$. This value was lower when compared with the Ca value for normal tofu $(47,493 \mathrm{mg} / \mathrm{kg})$. This is because the crude protein concentration was decreased during acid hydrolysis; therefore, the ca-protein binding was reduced. Comparing commercial tofu, for basic tofu production, soymilk is coagulated with one of the several coagulants used in the 
Table 2. Crude protein percentage in different types of Tofu.

\begin{tabular}{ccc}
\hline & Tofu sample type & Crude protein (\%) \\
\hline & Prosoy & 36.57 \\
Soybean Tofu with Hydrolysis & ND 1005T & 38.02 \\
& P.91M10 & 41.81 \\
Soybean Meal Tofu with & Mean \pm SD & $38.80 \pm 2.21$ \\
Hydrolysis & Northern Crops Institute & 42.80 \\
& Hubbard Feeds Inc. & 38.75 \\
Soybean Tofu in General & Mean \pm SD & $40.78 \pm 2.03$ \\
Process & Prosoy & 45.47 \\
& ND 1005T & 46.70 \\
Poybean Meal Tofu in General & Mean \pm SD & 37.97 \\
Process & Northern Crops Institute & $43.38 \pm 3.86$ \\
& Hubbard Feeds Inc. & 51.51 \\
& Mean \pm SD & 40.22 \\
Commercial Tofu & Azumaya firm tofu & $45.87 \pm 5.65$ \\
& Nasoya extra firm tofu & 55.78 \\
& Pulmuone soft tofu & 55.23 \\
& Melissa's extra firm tofu & 54.60 \\
& Wildwood firm sprou tofu & 53.82
\end{tabular}

$\mathrm{SD}=$ Standard deviation

Table 3. Micronutrient concentrations in different types of Tofu.

\begin{tabular}{|c|c|c|c|c|c|c|c|}
\hline & \multirow{2}{*}{ Tofu sample type } & \multicolumn{6}{|c|}{ Element concentrations (mg/kg) } \\
\hline & & $\mathrm{Ca}$ & $\mathrm{K}$ & $\mathrm{Mg}$ & $\mathrm{Zn}$ & $\mathrm{Fe}$ & $\mathrm{P}$ \\
\hline \multirow{3}{*}{$\begin{array}{c}\text { Soybean Tofu with } \\
\text { Hydrolysis }\end{array}$} & Prosoy & 20,401 & 29,956 & 2714 & 29 & 53 & 6329 \\
\hline & P.91M10 & 19,421 & 24,682 & 2150 & 0.3 & 7 & 7243 \\
\hline & Mean \pm SD & $21,774 \pm 2665$ & $27,618 \pm 2194$ & $2832 \pm 612$ & $13 \pm 12$ & $21 \pm 23$ & $6465 \pm 588$ \\
\hline \multirow{3}{*}{$\begin{array}{l}\text { Soybean Meal } \\
\text { Tofu with } \\
\text { Hydrolysis }\end{array}$} & Northern Crops Institute & 25,473 & 25,828 & 3113 & 0.1 & 1 & 3939 \\
\hline & Hubbard Feeds Inc. & 29,140 & 25,277 & 3354 & 0.03 & 0.2 & 1287 \\
\hline & Mean \pm SD & $27,307 \pm 1834$ & $25,553 \pm 275$ & $3233 \pm 120$ & $0.1 \pm 0.03$ & $0.7 \pm 0.5$ & $2613 \pm 1326$ \\
\hline \multirow{4}{*}{$\begin{array}{l}\text { Soybean Tofu in } \\
\text { General Process }\end{array}$} & Prosoy & 42,577 & 6472 & 3440 & 42 & 88 & 8994 \\
\hline & ND 1005T & 49,383 & 5440 & 3393 & 39 & 75 & 10,030 \\
\hline & P.91M10 & 56,706 & 8725 & 3814 & 34 & 66 & 8059 \\
\hline & Mean \pm SD & $49,555 \pm 5769$ & $6879 \pm 1312$ & $3549 \pm 188$ & $38 \pm 3$ & $76 \pm 9$ & $9028 \pm 805$ \\
\hline \multirow{2}{*}{$\begin{array}{l}\text { Soybean Meal } \\
\text { Tofu in General } \\
\text { Process }\end{array}$} & Hubbard Feeds Inc. & 24,051 & 18,875 & 2173 & 33 & 40 & 3404 \\
\hline & Mean \pm SD & $47,493 \pm 23442$ & $14,344 \pm 4531$ & $3019 \pm 846$ & $33 \pm 0.01$ & $39 \pm 1.1$ & $5234 \pm 1830$ \\
\hline \multirow{8}{*}{ Commercial Tofu } & Azumaya firm tofu & 14,744 & 6206 & 3577 & 8 & 56 & 8958 \\
\hline & Nasoya extra firm tofu & 6238 & 2980 & 6994 & 44 & 45 & 9134 \\
\hline & Pulmuone soft tofu & 6797 & 6145 & 3985 & 62 & 68 & 9594 \\
\hline & Melissa’s extra firm tofu & 10,914 & 4090 & 3687 & 59 & 71 & 12,630 \\
\hline & Wildwood firm sprou tofu & 6644 & 4172 & 1184 & 46 & 89 & 5590 \\
\hline & Mori-nu silken extra firm tofu & 2306 & 7844 & 1269 & 30 & 86 & 4585 \\
\hline & House feeds premium extra firm tofu & 5341 & 4651 & 1583 & 40 & 69 & 5150 \\
\hline & Mean \pm SD & $7569 \pm 3752$ & $5156 \pm 1531$ & $3183 \pm 1920$ & $41 \pm 17$ & $69 \pm 14.3$ & $7949 \pm 2719$ \\
\hline
\end{tabular}

$\mathrm{SD}=$ Standard deviation. 
US, such as $\mathrm{CaSO}_{4}$, calcium chloride $\left(\mathrm{CaCl}_{2}\right)$, magnesium sulfate $\left(\mathrm{MgSO}_{4}\right)$, nigari, or delta gluconolactone, which is a non dairy coagulant derived from corn starch. Accordingly, $\mathrm{Ca}$ and $\mathrm{Mg}$ concentrations were influenced depending on the types of coagulants. In comparison with commercial tofu and generally handmade tofu, hydrolyzed tofu showed higher concentrations of $\mathrm{K}$. The highest concentration of $\mathrm{K}$ was observed in Prosoy $(29,956 \mathrm{mg} / \mathrm{kg})$. The mean $\mathrm{K}$ concentration of defatted soybean meal tofu was $25,553 \mathrm{mg} / \mathrm{kg}$, whereas the mean $\mathrm{K}$ concentrations of the standard soybean tofu and soybean meal tofu with the same type of raw materials were $6819 \mathrm{mg} / \mathrm{kg}$ and 14,344 mg/kg, respectively. This is because in the process of hydrolyzed tofu making, $\mathrm{KOH}$ was added at the final step to neutralize the acid (i.e., $\mathrm{HCl})$. Soybeansareknown as a relatively rich source of $\mathrm{P}$, and are important for growth and bone integrity of livestock and poultry. However, through the results presented in Table 3, the concentration of $\mathrm{P}$ did not have any apparent properties. The micronutrients such as $\mathrm{Zn}$ and Fe were low in all types of tofu. Unfortunately, in the acidhydrolyzed soybean meal tofu, the concentrations of $\mathrm{Zn}$ and $\mathrm{Fe}$ were severely reduced to $0.06 \mathrm{mg} / \mathrm{kg}$ and 0.63 $\mathrm{mg} / \mathrm{kg}$, respectively.

\section{Conclusion}

By using soybean meal as a major ingredient, the hydrolyzed soybean meal tofu was devised not only as the cost-effective alternative of protein source to developing countries, but also richer source of phytoestrogen. Furthermore, newly applied tofu preparation which was used in the acid hydrolysis before coagulation of tofu, recorded maximum 8-fold increase in genistein and 12-fold increase in daidzein concentrations, respectively. Overall, the crude protein concentration and the micronutrient profile were ideal in the hydrolyzed soybean meal tofu. Even though this study showed the limitation of making tofu in a laboratory scale in terms of finding the optimal conditions, this modified tofu procedure enhanced the value of tofu as functional food.

\section{REFERENCES}

[1] A. Cassidy, J. Brown, A. Hawdon, M. Faughnan, L. King, J. Millward, L. Zimmer-Nechemias, B. Wolfe and K. Setchell, "Factors Affecting the Bioavailability of Soy Isoflavones in Humans after Ingestion of Physiologically Relevant Levels from Different Soy Foods,” American Society for Nutrition, Vol. 136, No. 1, 2006, pp. 45-51.
[2] J. Anderson, B. Smith and C. Washnock, "Cardiovascular and Renal Benefits of Dry Bean and Soybean Intake," The American Journal of Clinical nutrition, Vol. 70, No. 3, 1999, pp. 464-474.

[3] T. Akashi, T. Aoki and S. Ayabe, "Molecular and Biochemical Characterization of 2-Hydroxyisoflavanone Dehydratase. Involvement of Carboxylesterase-Like Proteins in Leguminous Isoflavone Biosynthesis," Plant Physiology, Vol. 137, No. 3, 2005, pp. 882-889. http://dx.doi.org/10.1104/pp.104.056747

[4] T. Kao, Y. Lu, H. Hsieh and B. Chen, "Stability of Isoflavone Glucosides during Processing of Soymilk and Tofu,” Food Research International, Vol. 37, No. 9, 2004, pp. 891-900.

http://dx.doi.org/10.1016/j.foodres.2004.05.007

[5] K. Setchell, N. Brown, P. Desai, L. Zimmer-Nechemias, B. Wolfe, W. Brashear, A. Kirschner, A. Cassidy and J. Heubi, "Bioavailability of Pure Isoflavones in Healthy Humans and Analysis of Commercial Soy Isoflavone Supplements,” American Society for Nutrition, Vol. 131, No. 4, 2001, pp. 1362-1375.

[6] I. Ogbuewu, A. Omede, O. Chukwuka, O. Iheshiulor, M. Uchegbu, A. Udebuani, B. Ekenyem, I. Okoli and M. Iloeje, "The Overview of the Chemistry, Health Benefits and the Potential Threats Associated with Prolonged Exposure to Dietary Soy Isoflavones,” International Journal of Agricultural Research, Vol. 5, No. 12, 2010, pp. 10841099. http://dx.doi.org/10.3923/ijar.2010.1084.1099

[7] W. Shurtleff and A. Aoyagi, "Tofu \& Soymilk Production: A Craft and Technical Manual," Soyinfo Center, Lafayette, 2001.

[8] L. Karr-Lilienthal, C. Kadzere, C. Grieshop and G. Fahey Jr., "Chemical and Nutritional Properties of Soybean Carbohydrates as Related to Nonruminants: A Review," Livestock Production Science, Vol. 97, No. 1, 2005, pp. 112. http://dx.doi.org/10.1016/j.livprodsci.2005.01.015

[9] D. Thavarajah, P. Thavarajah, A. Sarker and A. Vandenberg, "Lentils (Lens culinaris Medikus Subspecies culinaris): A Whole Food for Increased Iron and Zinc Intake," Journal of Agriculture and Food Chemistry, Vol. 57, No. 12, 2009, pp. 5413-5419. http://dx.doi.org/10.1021/jf900786e

[10] D. Shen, Q. Wu, W. Sciarappa and J. Simon, “Chromatographic Fingerprints and Quantitative Analysis of Isoflavones in Tofu-Type Soybeans," Food Chemistry, Vol. 130, No. 4, 2012, pp. 1003-1009. http://dx.doi.org/10.1016/j.foodchem.2011.07.121

[11] M. Prabhakaran, C. Perera and S. Valiyaveettil, "Effect of Different Coagulants on the Isoflavone Levels and Physical Properties of Prepared Firm Tofu," Food Chemistry, Vol. 99, No. 3, 2006, pp. 492-499. http://dx.doi.org/10.1016/j.foodchem.2005.08.011 